\title{
Consumption of antihypertensive drugs dispensed under the pharmacy benefit management program
}

\author{
Aline Pereira Rocha, Brigitte Rieckmann Martins dos Santos* \\ School of Pharmacy, Municipal University of São Caetano do Sul
}

\begin{abstract}
Pharmacy benefit management (PBM) programs provide attractive discounts for drug purchase, a relevant measure to address costs, mainly of drugs for the treatment of chronic diseases. This study investigated whether PBM may be used as a tool to provide information about the use of antihypertensive medications when they are purchased. The profile of medicines taken to treat high blood pressure by large IT company employees and their dependents was evaluated from January to December 2009. The mean rate of drug boxes purchased to control hypertension was $9.4 \pm 10.0$ in 2009. Men purchased more drugs than women. The number of drugs purchased for the treatment of hypertension was lower than expected in all age groups except for individuals aged 54-58 and $>59$ years. Among men, the purchase of drugs to treat hypertension was higher than expected in the 24-28, 34-38 and 54-58 age groups. Among women, results matched expectations, except for the age group 34-38 years, in which purchase was lower than expected. Individuals in the age group 0-18 years were found to consume antihypertensive drugs. Although the PBM system may be used to identify drugs purchased by users, it does not ensure patient adherence to recommended drug treatment to control hypertension.
\end{abstract}

Uniterms: Hypertension. Antihypertensive drugs. Drugs/continuous use. Antihypertensive medications/ use. Treatment adherence. Drug therapy/adherence to treatment. Medicines/benefit manegement.

O objetivo do Programa de Benefícios em Medicamentos (PBM) é proporcionar descontos atraentes para aquisição de medicamentos, um fator relevante para o custo, principalmente no tratamento de doenças crônicas. O objetivo deste estudo é comprovar se o PBM pode ser utilizado como ferramenta para o fornecimento de informações sobre o consumo de medicamentos antihipertensivos através da aquisição dos mesmos. Foi realizada análise do perfil de medicamentos adquiridos para o tratamento de hipertensão arterial sistêmica por funcionários e seus dependentes de uma empresa de grande porte na área de tecnologia de informação (TI) no período compreendido entre janeiro a dezembro de 2009. A taxa de aquisição média de medicamentos para o controle da hipertensão foi de $9,4 \pm 10,0$ embalagens durante o ano de 2009. Os homens consumiram mais caixas de medicamentos que as mulheres. O número de caixas de medicamentos adquiridas para o tratamento da hipertensão arterial foi abaixo do esperado em todas as faixas de idade, exceto para 54-58 e >59 anos. Entre os homens, a aquisição de caixas de medicamentos para o tratamento da hipertensão arterial foi maior que o esperado nas seguintes faixas de idade: $24-28$, 34-38 e 54-58 anos. Entre as mulheres, a aquisição de caixas de medicamentos antihipertensivos foi dentro do esperado, exceto para aquelas com idade compreendida entre 34-38 anos que foi abaixo do esperado. Observou-se a existência de consumo de fármacos antihipertensivos na faixa etária de 0-18 anos. Embora o sistema de PBM permita identificar a aquisição de medicamentos antihipertensivos por seus usuários, não garante que os pacientes estejam aderidos à terapia medicamentosa recomendada para o controle da hipertensão.

Unitermos: Hipertensão. Fármacos anti-hipertensivos. Anti-hipertensivos/uso. Medicamentos de uso contínuo. Terapia medicamentosa/adesão ao tratamento.

*Correspondence: B. R. M. Santos. Escola da Saúde, Universidade Municipal de São Caetano do Sul. Rua Santo Antonio, 50, 09521-050 - São Caetano do Sul - São Paulo, Brazil. E-mail: brigitterie@yahoo.com.br 


\section{INTRODUCTION}

Access to medicines is an indicator of both quality and effectiveness of the public health system, as well as a determinant factor for patient adherence to prescription treatments, mainly in the treatment of chronic degenerative diseases, such as high blood pressure (Halal et al., 1994; Paniz et al., 2008).

Although public healthcare services and systems in Brazil have progressed positively, their main challenge is to provide the population access to essential medicines. According to Guerra Jr. et al (2004) and Vieira and Zucchi (2007), more than 70 million Brazilians had no access to medicines in 2000. This is a matter of concern because medicines are an essential issue for effective health care.

High blood pressure is defined as an asymptomatic disease (Sociedade Brasileira de Cardiologia, 2010) whose symptoms are observed only when complications (mainly cardiovascular) occur. It increases costs of both hospital admissions and specialized treatments (Sociedade Brasileira de Cardiologia, Sociedade Brasileira de Hipertensão, Sociedade Brasileira de Nefrologia, 2010). According to data published by the Brazilian Ministry of Health, more than 1,150,000 hospital admissions per year are recorded in the Unified Health System (Sistema Único de Saúde, SUS) at a total cost of US\$ 305 million (R\$475 million; Brasil, 2009). Non-transmissible chronic diseases are also one of the main causes of disability retirement and temporary disability (Moura, Carvalho, Silva, 2007).

Because systemic hypertension usually presents in its asymptomatic form, many hypertensive individuals are either not identified or have low treatment compliance after diagnosis. One of the reasons for low treatment compliance is associated with social conditions, especially purchase of expensive medicines (Mion Jr. et al., 2006; Lessa, 2006) and treatment complexity, when the patient has to take many doses per day (Sica, 2002). The annual cost for treatment of hypertension in the Unified Health System (Sistema Único de Saúde, SUS) was US\$ 621,302,202.56 (R \$ 969,231,436.00), and in the National Supplementary Health Agency (NSHA), US\$ $424,773,685.90(\mathrm{R} \$ 662,646,950.00)$. The total cost of hypertension treatment accounted for $0.08 \%$ of the Brazilian gross domestic product (Produto Interno Bruto, PIB) in 2005 (Sociedade Brasileira de Cardiologia, Sociedade Brasileira de Hipertensão, Sociedade Brasileira de Nefrologia, 2010).

The study of consumption of antihypertensive drugs may be greatly valuable for patient monitoring. The investigation of cost/utility, cost/effectiveness, or cost/benefit ratios in the use of medicines should include all costs associated with the treatment of patients, including medical visits, hospital admission, laboratory tests, nursing care, and social and mental health services (São Paulo, 2010). However, because of the difficulties in conducting complete analyses of treatment costs, several studies are limited to comparisons between costs of different medicines, which should be those at the time the medicine is prescribed because treatment indications last for the patient's lifetime (Pearce et al., 1998). Therefore, private interests in drug development and provision have increased to ensure investments in both health care and drug management to minimize costs of non-drug treatments and reduce inadequate treatments and possible undesirable hospital admissions (Sousa, 2010).

Of the drug benefits offered by managed health care companies, the most sought by users is the pharmacy benefit management - PBM (Programa de Beneficios em Medicamentos, $P B M)$, which facilitates access to medicines (Agência Nacional de Saúde Suplementar, ANS; Brasil, 2010a). However, few studies have investigated the potential of the PBM program in Brazil. According to Lima et al. (2008), the PBM program comprises independent managed health care companies that manage benefits while selling medicines based on cost minimization, value aggregation, and strengthening of trade relationships to obtain operational advantages that meet the interests of the main agents involved: employers (companies that contract the system and pharmaceutical retailing), drugstores, and the pharmaceutical industry. However, the PBM system also seems to be able to provide relevant information about the profile of antibiotic prescription and purchase.

The databases of PBM companies are made up of information obtained from medicine purchases using a PBM card at licensed drugstores, and data are stored in an authorizer on-line server. This study described the characteristics of antihypertensive drug consumption according to drug class and number of packages purchased using data about the purchase of drugs to control high blood pressure.

\section{MATERIAL AND METHODS}

The database used in this study was obtained from a PBM agency in the city of São Caetano do Sul, Brazil, which also has employees also in other Brazilian states (Rio de Janeiro, Rio Grande do Sul, Ceará, and Distrito Federal). In this IT company, PBM is one of the benefits provided to all active and retired employees and their dependents. This benefit provides a $75 \%$ discount rate for the 
purchase of prescribed medicines. It also records medicine prescriptions and their purchase by all employees and their dependents.

The database is built as beneficiaries use their PBM cards at the licensed drugstores when paying for antihypertensive medication. Information in the card ensures online authorization, confirms the recipient's eligibility for benefits under the PBM program, and validates data. The following items are recorded at the time of purchase: the registration number of the prescriber, the expiration date of the prescription, name, age and sex of the beneficiary, the number of boxes, name of the medicines and drug class. Finally, a confirmation of purchased drugs withdrawal is delivered to the beneficiary for salary discounts. Medical reports from this database are obtained using Excel 2007 and provided to the managers of companies that contracted this benefit.

The IT company had 31,000 records of active employees, retirees and dependents who were entitled to the medicine benefits. All antihypertensive drugs used by the PBM beneficiaries in the IT company from January to December 2009, regardless of beneficiary age, were included in the study. Medicines not used in the treatment of high blood pressure were not included. In 2009, 2,798 (9.03\%) employees (1,537 men) purchased antihypertensive medicines using the PBM program. A medicine profile was outlined according to sex and age range.

To ensure data confidentiality, the IT company, prescribers and patients were not identified. This study was approved by the Research Ethics Committee of the Municipal University of São Caetano do Sul.

The Anatomical Therapeutic Chemical (ATC) classification system, established by the World Health Organization (World Health Organization, 2010), was used to analyze antihypertensive drugs. Data were analyzed using the Statistical Package for the Social Sciences (SPSS) 17.0 for Windows. Quantitative variables are described as frequency and measures of central tendency and dispersion. The Mann-Whitney U test was used to compare sex differences and the level of significance was set at 0.05 (Hair et al., 2005; Pestana and Gageiro, 2008).

\section{RESULTS}

Table I shows that each employee purchased a mean $9.4 \pm 10.0$ medicine boxes during the time under study. Men purchased more drugs than women $(p \leq 0.001)$.

Table II shows the mean number of medicine boxes purchased by different age groups. A CI-based classification was derived from results, as "low", "expected", and "high", for mean values that are bellow, within, or above
TABLE I - Purchase of medicine boxes according to sex (JanuaryDecember, 2009)

\begin{tabular}{|c|c|c|c|c|}
\hline \multirow{2}{*}{ Sex } & \multirow{2}{*}{ Mean value } & \multirow{2}{*}{$\mathrm{SD}$} & \multicolumn{2}{|c|}{ Confidence interval } \\
\hline & & & LL & $\mathrm{UL}$ \\
\hline Male* & 10.3 & 10.4 & 9.8 & 10.8 \\
\hline Female & 8.3 & 9.4 & 7.7 & 8.8 \\
\hline Total & 9.4 & 10.0 & 9.0 & 9.7 \\
\hline
\end{tabular}

the CI. Therefore, based on the $95 \%$ confidence interval $(95 \% \mathrm{CI})$, the number of medicine boxes purchased was lower than expected for all age groups, except for the groups $54-58$ and $>59$ years, both with results above expected.

TABLE II - Purchases of medicine boxes in 2009 according to age group (January-December, 2009)

\begin{tabular}{lcccc}
\hline $\begin{array}{l}\text { Age groups* } \\
\text { (years) }\end{array}$ & $\begin{array}{l}\text { Mean } \\
\text { value }\end{array}$ & SD & \multicolumn{2}{c}{ Confidence interval } \\
\hline $0-18$ & 2.5 & 1.2 & 1.2 & 3.8 \\
$19-23$ & 2.3 & 2.8 & 0.5 & 4.1 \\
$24-28$ & 4.7 & 4.8 & 3.4 & 6.1 \\
$29-33$ & 6.1 & 7.1 & 5.2 & 6.9 \\
$34-38$ & 6.8 & 9.0 & 5.7 & 7.9 \\
$39-43$ & 7.3 & 7.0 & 6.4 & 8.0 \\
$44-48$ & 8.1 & 10.5 & 6.9 & 9.3 \\
$49-53$ & 8.7 & 8.6 & 7.7 & 9.6 \\
$54-58$ & 10.1 & 10.8 & 9.1 & 11.2 \\
$>59$ & 12.5 & 11.0 & 11.7 & 13.2 \\
\hline
\end{tabular}

* $p \leq 0.05$; SD: standard deviation; LL: lower limits; UL: upper limits; Level of significance: 0.001

As indicated by $95 \%$ IC values and shown in Figure 1 , the number of medicine boxes purchased by men was expected in the age groups $0-18,19-23,29-33,39$ $43,44-48,49-53$, and $>59$ years. In the other age groups (24-28, 34-38, and 54-58), consumption was higher than expected. Among women, the purchase of medicine boxes was expected for all age groups except in the group 34-38 years, in which it was lower than expected.

Table III shows that the purchase of $\beta$ blockers $(31.3 \%)$ was the highest, followed by pure $(29.0 \%)$ and combined angiotensin II antagonists (25.7\%), and pure ACE inhibitors (19.9\%) and calcium antagonists (17.3\%), but there were no statistical differences. 


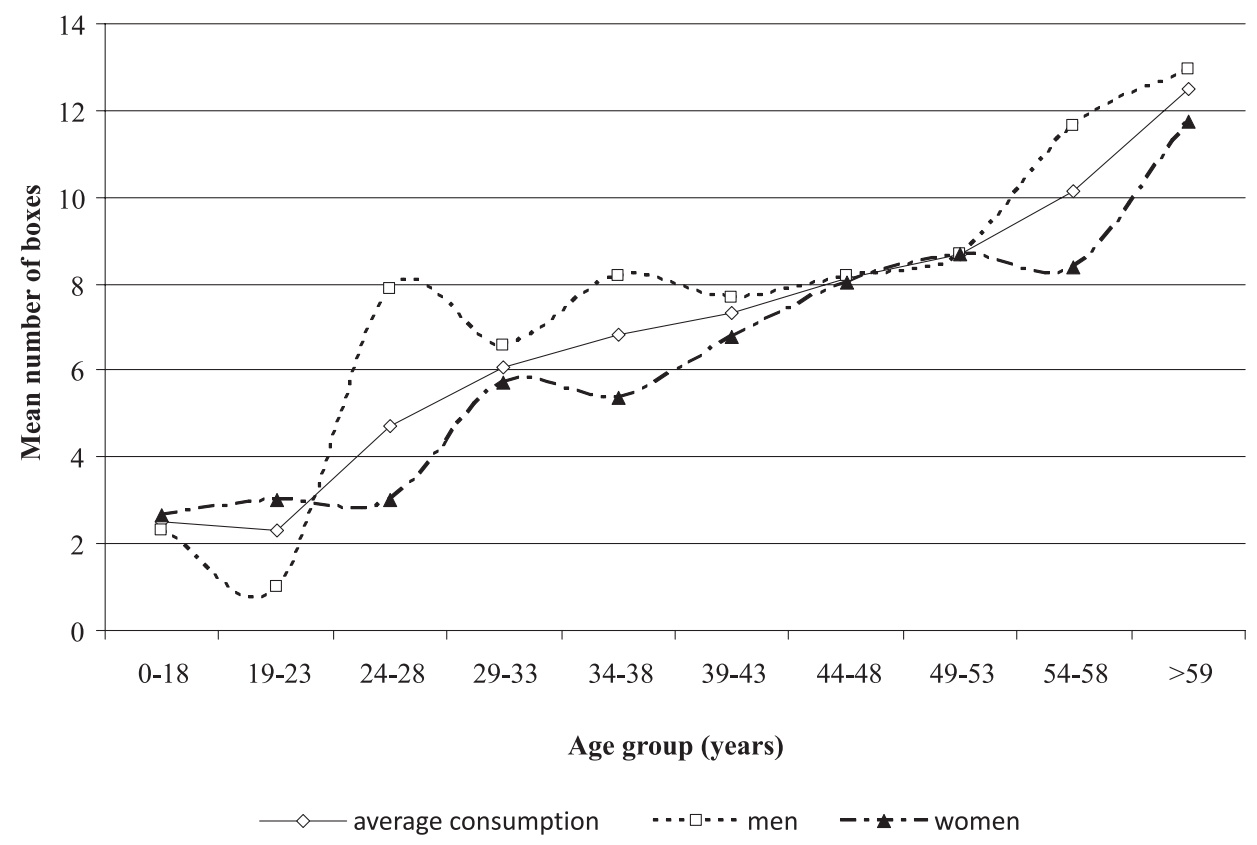

FIGURE 1 - Purchases of medicine boxes according to sex and age group (January-December, 2009).

TABLE III - Purchases of medicine boxes according to drug classes and sex

\begin{tabular}{|c|c|c|c|c|c|c|}
\hline \multirow{3}{*}{ Drug class } & \multicolumn{4}{|c|}{ Sex } & \multirow{2}{*}{\multicolumn{2}{|c|}{ Total }} \\
\hline & \multicolumn{2}{|c|}{ Male } & \multicolumn{2}{|c|}{ Female } & & \\
\hline & $\mathrm{N}$ & $(\%)$ & $\mathrm{N}$ & $(\%)$ & $\mathrm{N}$ & $(\%)$ \\
\hline$\beta$ blockers & 456 & $(16.3)$ & 421 & $(15.0)$ & 877 & $(31.3)$ \\
\hline Potassium-sparing diuretics + loop diuretics & 7 & $(0.25)$ & 10 & $(0.3)$ & 17 & $(0.6)$ \\
\hline Potassium-sparing diuretics + thiazide diuretics (and/or analogs) & 80 & $(2.9)$ & 76 & $(2.7)$ & 156 & $(5.6)$ \\
\hline Potassium-sparing diuretics & 48 & $(1.7)$ & 84 & $(3.1)$ & 132 & $(4.7)$ \\
\hline Angiotensin II antagonists (combined) & 429 & $(15.3)$ & 290 & $(10.4)$ & 719 & $(25.7)$ \\
\hline Angiotensin II antagonists (pure) & 498 & $(17.8)$ & 314 & $(11.2)$ & 812 & $(29.0)$ \\
\hline Calcium channel blockers $+\beta$ blockers & 12 & $(0.4)$ & 7 & $(0.25)$ & 19 & $(0.7)$ \\
\hline Calcium channel blockers & 280 & $(10.0)$ & 203 & $(7.3)$ & 486 & $(17.3)$ \\
\hline Centrally-acting agonists & 13 & $(0.5)$ & 36 & $(1.3)$ & 49 & $(1.7)$ \\
\hline Peripherally-acting adrenergic antagonists & 10 & $(0.4)$ & 7 & $(0.25)$ & 17 & $(0.6)$ \\
\hline Antihypertensive drugs + diuretics & 98 & $(3.5)$ & 91 & $(3.25)$ & 189 & $(6.7)$ \\
\hline Loop diuretics & 65 & $(2.3)$ & 88 & $(3.1)$ & 153 & $(5.5)$ \\
\hline ACE inhibitors + calcium channel blockers & 46 & $(1.6)$ & 23 & $(0.8)$ & 69 & $(2.5)$ \\
\hline ACE inhibitors + antihypertensive drugs & 66 & $(2.3)$ & 38 & $(1.3)$ & 104 & (3.7) \\
\hline ACE inhibitors & 332 & $(11.9)$ & 224 & $(8.0)$ & 556 & $(19.9)$ \\
\hline Other diuretics & 0 & 0 & 2 & $(0.07)$ & 2 & $(0.07)$ \\
\hline Thiazide diuretics and analogs & 201 & $(7.2)$ & 220 & (7.9) & 421 & $(15.0)$ \\
\hline TOTAL & 1537 & $(54.9)$ & 1261 & $(45.1)$ & 2798 & $(100)$ \\
\hline
\end{tabular}




\section{DISCUSSION}

Data from the Ministry of Health show that high blood pressure affects $24.4 \%$ of the Brazilian population, and this rate is as high as $50 \%$ in the age range of 50-59 years, reaching $75 \%$ among persons aged $>75$ years $(\mathrm{Ce}-$ sarino et al. 2008; Rosario et al. 2008). The prevalence of hypertension among men is higher (35.8\%) than among women (30\%) (Pereira et al. 2009).

Other studies showed that several measures, such as continuous medicine therapy, changes in life style (education and self care), and regular medical visits, are used to control high blood pressure. However, Péres, Magna, Viana (2003) confirmed other studies that found that the challenge in blood pressure control lies in patient adherence to treatment, because patients with hypertension usually do not adhere to treatment and, among those who adhere, few have their high blood pressure controlled.

In Brazil, the government is responsible for providing health care as a fundamental right of all human beings, and should formulate and execute economic and social policies to ensure universal and equal access to health care, as well as health promotion, protection, and recovery (Brasil, 1990). At the same time, about 44 million Brazilians are beneficiaries of individual or collective managed health care programs in the country (Agência Nacional de Saúde Suplementar, Brasil, 2010b).

In this context in Brazil and as an essential part of the National Health Policy (NHP; Politica Nacional de Saúde, PNS), the objective of the National Medicine Policy (NMP; Politica Nacional de Medicamentos, PNM) is to provide access and rational use of essential medicines to the population and to ensure safety, efficacy, and quality (Brasil, 2000). The NMP guidelines are directed to the revision of the National List of Essential Medicines (NLEM; Relação Nacional de Medicamentos Essenciais, RENAME), the regulation of medicines by health care authorities, technical and scientific development, development and qualification of human resources, and the reorganization of pharmaceutical assistance (Oliveira, Labra, Bermudez, 2006).

The Brazilian Ministry of Health created the Popular Pharmacy Program (PPP; Programa Farmácia Popular, $P F P)$ to amplify population access to medicines. PPP has its own popular pharmacy network, currently with 108 medicines for the treatment of patients with dyslipidemia, diabetes, and high blood pressure. Such medicines are dispensed at reference values, with a reduction of up to $90 \%$ of the value charged in commercial pharmacies and drugstores, and can only be purchased with a medical prescription (Brasil, 2010c). Recently, the campaign "health is priceless" has been launched to provide free medications indicated for the treatment of hypertension and diabetes in pharmacies licensed by the PPP (Programa Farmácia Popular, PFP, Brasil, 2011).

However, according to the National Council of State Secretaries of Health (NCSSH; Conselho $\mathrm{Na}$ cional de Secretários Estaduais de Saúde, CONASS, 2010), medicines in Brazil and Uruguay have the highest prices in the American continent. In addition, there is no information on the degree of success of the treatments prescribed. Because there is not a system to follow the treatment of patients, a pharmacy assistance program to verify and follow up patient adherence to treatment should be implemented to ensure adequate changes in treatment protocols.

According to Lima et al. (2008), PBM was created in the US in the 1970s when labor unions required employers to include medicines in their benefit programs. Between the late 1980s and early 1990s, the demand for prescribed medicines from PBM had a 30\% increase. The action of managed care companies, cost managers in the health area, and the spread of PBM companies led to a large increase in the consumption of medicines in the USA. In Brazil, the concept of PBM is relatively new and appeared in the market in the late 1990s.

According to Taniguchi (1995), the main functions of PBM are:

1. Deal with the drugstore chains to ensure that accessible geographical sites are available to recipients;

2. Process medicine requests trough a network of drugstores where request transmission is automatic and based on the eligibility rules established between the contracting companies;

3. Send customized reports to the operators to ensure cost management and medicine consumption;

4. Create health compliance and disease management programs that inform the contracting companies about patients that do not follow the treatment as recommended by the physicians. Besides giving information to the contracting companies, PBM physicians and pharmacists carry out programs to educate chronic users, develop their self-knowledge and encourage lifestyle changes, always according to guidelines from medical societies;

5. Obtain discounts from the pharmaceutical industry after negotiations so that their medicines are included in the basic PBM lists, which are based on medical consensus and enable users to choose one of a group of drugs in the same therapeutic class. The lists are reviewed and updated by the pharmaceutical and clinical committee of the PBM, and; 
6. Evaluate treatment outcomes according to the database that includes all health care data (medicine requests, treatment compliance, and medicine consumption), which enables the development of adequate tools to monitor the incidence of events.

In the company studied, $9.03 \%$ of the individuals who used the pharmacy benefit purchased a mean $9.4 \pm 10.0$ boxes of antihypertensive drugs. Men purchased more drugs than women, which may be explained by a higher prevalence of high blood pressure among men. Men tend to seek health care less frequently (unhealthy behavior) than women (Gomes et al. 2007; Figueiredo, 2005). Regarding age range, purchase of antihypertensive drugs by men was higher than expected among those aged 24-28, 34-38, and 54-58 years. Among men in the other age groups, purchase was within the expected range. In the female population, purchase was expected in all age groups, except among women aged 34-38 years, in which case the number of purchases was lower than expected.

In this study, purchase of antihypertensive drugs by people aged 0-18 years was remarkable. In Brazil, about 3.5 million children and teenagers $(5 \%$ of the Brazilian population) have hypertension (Sociedade Brasileira de Cardiologia, Sociedade Brasileira de Hipertensão e Sociedade Brasileira de Nefrologia, 2010). Under physiological conditions, systolic blood pressure increases from the age of one year until adolescence, whereas diastolic blood pressure increases only after the age of 5-6 years (NIH, 2004).

According to some studies, the prevalence of high blood pressure has a secondary cause among young children, and may include pathologies such as thrombosis, renal artery stenosis, and coarctation of the aorta. At the same time, primary hypertension is prevalent among adolescents (Araújo et al., 2007). Studies show that lifestylerelated factors, such as nutrition, lipid profile, obesity, sedentary habits, and tobacco smoking are potential causes of atherosclerosis whose contribution begins in childhood (Araújo et al., 2007; Lancarotte, 2010; Nobre et al., 2006; Pellanda et al., 2002).

In this study, $\beta$-blockers were the antihypertensive drugs with the highest consumption (31.3\%). According to Machuca and Parras (2003), $\beta$-adrenergic blockers are among the first-choice drugs for the treatment of patients with systemic hypertension because they decrease both heart rate and myocardial contractility in addition to decreasing blood-pressure levels. However, diuretics are the most frequently used antihypertensive drugs because they cause a significant decrease in morbidity and mortality (Sociedade Brasileira de Cardiologia, 2010). In addition, they are less expensive and more efficient in preventing one or more main forms of cardiovascular disease.

According to Ribeiro (2005), the use of antihypertensive drugs for the treatment of patients with this disease is essential. However, single-drug treatments result in reductions of systolic and diastolic pressures of only 4-8\% of the initial values. At the same time, patients treated with the combination or association of two antihypertensive drugs may show an $8-15 \%$ decrease in blood pressure levels. In addition, the prescription of medicines with few side effects is increasingly frequent due to concerns about both compliance with the prescribed treatment and patient quality of life.

Milagres et al. (2005) suggest that angiotensin I converting enzyme (ACE) inhibitors should receive attention because of their low incidence of side effects, such as cough and headaches. In turn, drug treatments and lifestyle changes are highly recommended because reductions in sodium intake, body weight control, and regular physical activity reduce morbidity and mortality due to cardiovascular diseases (Sociedade Brasileira de Cardiologia, Sociedade Brasileira de Hipertensão, Sociedade Brasileira de Nefrologia, 2010).

The fact that patients purchase their medicines using the PBM program does not ensure their adherence to treatment. Many reasons may explain nonadherence, such as adverse drug effects, poor instructions, poor providerpatient relationship, poor memory, and patient disagreement with the need for treatment or inability to afford medication (Gusmão, Mion, Pierin, 2009; Ortega et al., 2010). According to Giorgi (2006), to adhere to treatment, patients should know their own health conditions and the importance of blood pressure control, and should have access to health services. These services should ensure that patients follow treatments throughout their lives.

\section{CONCLUSIONS}

Pharmacy benefit management (PBM) describes benefit programs that enable access to medicines through integrated information management. PBM is a useful tool to control and investigate medicine use profile, and may be used to identify and follow up medicine purchases for the treatment of patients diagnosed with chronic pathologies. However, PBM does not ensure that the user will take the therapeutic measures to keep blood pressure under control, or that medical prescriptions will be followed. In other words, PBM cannot evaluate medication consumption by patient or their adherence to antihypertensive treatment. Together with the use of the PBM tool, preventive medicine programs should be developed to monitor treatment, 
medical visits and changes in lifestyle (reduction of body weight, and physical activity), and should also include periodical phone calls or emails to enhance patient adherence to antihypertensive treatment.

\section{ACKNOWLEDGEMENTS}

The authors thank Dr Paulo Boschov, former professor at UNIFESP, for his revision of the final version of this manuscript.

\section{REFERENCES}

ARAÚJO, T.L.; LOPES, M.V.O.; MOREIRA, R.P.; CAVALCANTE, T.F.; GUEDES, N.G.; SILVA, V.M. Pressão arterial de crianças e adolescentes em uma escola pública de Fortaleza - Ceará. Acta Paul. Enferm., v.20, n.4, p.476-482, 2007.

BRASIL Lei $\mathrm{N}^{\circ} 8.080$, de 19 de setembro de 1990. Dispõe sobre as condições para a promoção, proteção e recuperação da saúde, a organização e o funcionamento dos serviços correspondentes e dá outras providências. Diário Oficial da União, Brasília, 20 sept. 1990. Seção 1, p.18.055.

Ministério da Saúde. Política Nacional de Medicamentos. Rev. Saúde Pública, v.34, n.2, p.206-209, 2000.

Ministério da Saúde. Hiperdia. Available at: <http:// hiperdia.datasus.gov.br>. Accessed on: 15 sept. 2009.

Ministério da Saúde. Agência Nacional de Saúde Suplementar e Assistência Farmacêutica: Cenário atual e perspectiva. Available at: $<$ http://www.ans.gov. br/portal/upload/biblioteca/TT_AS_10_GMosegui_ AssistenciaFarmaceutica.pdf $>$. Accessed on: 01 aug. 2010a.

Ministério da Saúde. Agência Nacional de Saúde Suplementar. Regulação \& Saúde: estrutura, evolução e perspectivas da assistência médica suplementar. Available at: $<$ http://bvsms.saude.gov.br/bvs/publicacoes/regulacao_ saude.pdf $>$. Accessed on: 01 aug. 2010b.

Ministério da Saúde. Farmácia Popular. Available at: $<$ http://portal.saude.gov.br/portal/saude/area.cfm?id_ area $=360$. . Accessed on: 18 mar. 2010c.

Ministério da Saúde. Saúde não tem preço: remédios de graça para hipertensão e diabetes. Available at: $<$ http:// www.saudenaotempreco.com/index.php $>$. Accessed on: 29 july 2011.
CESARINO, C.B.; CIPULLO J.R.; MARTIN, J.F.V.; CIORLIA, L.A.; GODOY, M.R.P.; CORDEIRO, J.A.; RODRIGUES, J.C. Prevalência e fatores sociodemográficos em hipertensos de São José do Rio Preto. Arq. Bras. Cardiol., v.91, n.1, p.31-35, 2008.

CONSELHO NACIONAL DE SECRETÁRIOS DE SAÚDE. CONASS. O desafio do acesso a medicamentos nos sistemas públicos de saúde: relatório do Seminário Internacional de Assistência Farmacêutica do Conass. Brasília: CONASS, 2010. 108 p. (Série Conass Documenta; n.20).

FIGUEIREDO, W. Assistência à saúde dos homens: um desafio para os serviços de atenção primária. Ciênc. Saúde Coletiva, v.10, n.1, p.105-109, 2005.

GIORGI, D.M.A. Estratégias para melhorar a adesão ao tratamento anti-hipertensivo. Rev. Bras. Hipertens., 2006; v.13, n.1, p.47-50, 2006.

GOMES, R.; NASCIMENTO, E.F.; ARAUJO, F.C. Por que os homens buscam menos os serviços de saúde que as mulheres? As explicações de homens com baixa escolaridade e homens com ensino superior. Cad. Saúde Pública, v.23, n.3, p.565-574, 2007.

GUERRA JÚNIOR, A.A.; ACÚRCIO, F.A.; GOMES, C.A.P.; MIRALLES, M.; GIRARDI, S.N.; WERNECK, G.A.F.; CARVALHO, C.L. Disponibilidade de medicamentos essenciais em duas regiões de Minas Gerais, Brasil. Rev. Panam. Salud Pública, v.15, n.3, p.168-175, 2004.

GUSMÃO, J.L.; MION Jr, D.; PIERIN, A.M.G. Health-related quality of life and blood pressure control in hypertensive patients with and without complications. Clinics, v.64, n.7, p.619-628, 2009.

HAIR, J.F.; ANDERSON, R.E.; TATHAM, R.L.; BLACK, W.C. Análise multivariada de dados. 5.ed. Porto Alegre: Bookman, 2005. $600 \mathrm{p}$.

HALAL, I.; SPARRENBERGER, F.; BERTONI, A.M.; CIACOMET, C.; SEIBEL, C.E., LAHUDE, F.; MAGALHÃES, A.G.; BARRETO, L.; LIRA, R.C.A. Avaliação da qualidade de assistência primária à saúde em localidade urbana na região sul do Brasil. Rev. Saúde Pública, v.28, n.2, p.131-136, 1994. 
LANCAROTTE, I.; NOBRE. M.R.; ZANETTE, R.; POLYDORO, M. Estilo de vida e saúde cardiovasculares em adolescentes de escolas do município de São Paulo. Arq. Bras. Cardiol., v.95, n.1, p.61-69, 2010.

LESSA, I. Impacto social de não adesão ao tratamento da hipertensão arterial. Rev. Bras. Hipertens., v.13, n.1, p.3046, 2006.

LIMA, A.P.C.; GALLANI, N.R., TOLEDO, M. I.; LOPES, L.C. Utilização de um sistema de gerenciamento de benefícios farmacêuticos (PBM) para a caracterização do perfil de prescrição e aquisição de antibióticos. Rev. Bras. Ciênc. Farm., v.44, n.2, p.215-223, 2008.

MACHUCA, M.; PARRAS, M. Guia de seguimento farmacoterapêutico sobre hipertension. España: Universidade de Granada. Available at: $<$ http://www.ugr. es/ cts 131/esp/guias/GUIA_HIPERTENSION.pdf $>$. Accessed on: 01 aug. 2010.

MILAGRES, R.; UEHARA, M.H.; ZANELLA, M.T.; PLAVNIK F.L.; KOHLMAN Jr, O. Estudo aberto, randomizado, comparativo da combinação fixa de anlodipino e enalapril em uma única formulação galênica versus anlodipino e enalapril isoladamente em pacientes hipertensos primários estágio 1 e 2 e diabéticos do tipo 2 - subestudo do estudo EMBATES. Rev. Bras. Hipertens., v.12, supl.1, p.32-41, 2005.

MION Jr, D.; SILVA, G.V.; ORTEGA, K.C.; NOBRE, F.A. Importância da medição anti-hipertensiva na adesão ao tratamento. Rev. Bras. Hipertens., v.13, n.1, p.55-58, 2006.

MOURA, A.A.G.; CARVALHO, E.F.; SILVA, N.J.C. Repercussão das doenças crônicas não transmissíveis na concessão de benefícios para a previdência social. Ciênc. Saúde Coletiva, v.12, n.6, p.1661-1672, 2007.

NATIONAL INSTITUTES OF HEALTH. NIH. The fourth report on the diagnoses, evaluation, and treatment of high blood pressure in children and adolescents. Pediatrics, v.114, n.2, p.555-576, 2004.

NOBRE, M.R.C.; DOMINGUES, R.Z.L.; SILVA, A.R.; COLUIGNOT, F.A.B.; TADDE, J.A.A.C. Prevalência de sobrepeso, obesidade e hábitos de vida associados ao risco cardiovascular em alunos do ensino fundamental. Rev. Assoc. Med. Bras., v.52, n.2, p.118-124, 2006.
OLIVEIRA, E.A.; LABRA, M.E.; BERMUDEZ, J. A produção pública de medicamentos no Brasil: uma visão geral. Cad. Saúde Pública, v.22, n.11, p.2379-2389, 2006.

ORTEGA, K.C.; GUSMÃO, J.L.; PIERIN, A.M.G.; NISHIURA, J.L.; IGNEZ, E.C.; SEGRE, C.A.; VENTURA, C.G.; MANO, G.P.; FONTES, V.; CUNHA, F.M.; MION Jr, D. How to avoid discontinuation to anthypertensive treatment. The experience in São Paulo, Brazil. Clin. Sci., v.65, n.9, p.857-863, 2010.

PANIZ, V.M.V.; FASSA, A.C.G.; FACCHINI, L.A.; BERTOLDI, A.D.; PICCINI, R.X.; TOMASI, E.; THUMÉ, E.; SILVEIRA, D.S.; SIQUEIRA, F.V.; RODRIGUES, M.A. Acesso a medicamentos de uso contínuo em adultos e idosos nas regiões Sul e Nordeste do Brasil. Cad. Saúde Pública, v.24, n.2, p.267-280, 2008.

PEARCE, K.A.; FUBERG, C.D.; PSATY, B.M.; KIRK, J. Cost-minimization and the number needed to treat in uncomplicated hypertension. Am. J. Hypertens., v.11, n.5, p.618-629, 1998.

PELLANDA, L.C.; ECHENIQUE, L.; BARCELLOS, L.M.A.; MACCARI, J.; BORGES, F.K.; ZEN, L.B. Doença coronariana isquêmica e prevenção iniciada durante a infância. J. Pediatria, v.78, n.2, p.91-96, 2002.

PEREIRA, M.; LUNET, N.; AZEVEDO, A.; BARROS, H. Differences in prevalence, awareness, treatment and control of hypertension between developing and developed countries. J. Hypertens., v.27, n.5, p.963-975, 2009.

PÉRES, D.S.; MAGNA, J.M.; VIANA, L.A. Portador de hipertensão arterial: atitudes, crenças, percepções, pensamentos e práticas. Rev. Saúde Pública, v.37, n.5, p.635-642, 2003.

PESTANA, M.H.; GAGEIRO, J.N. Análise de dados para ciências sociais: a complementaridade do SPSS. 5.ed. Lisboa: Edições Silabo, 2008. 694 p.

RIBEIRO, A.B. Associações fixas de anti-hipertensivos: a nova tendência. Rev. Bras. Hipertens., v.12, n.1, p.5-6, 2005.

ROSARIO, T.M.; SCALA, L.C.N.S.; FRANÇA, G.V.A.; PEREIRA M.R.G.; JARDIM, P.C.B.V. Prevalência, controle e tratamento da hipertensão arterial sistêmica em Nobres, MT. Arq. Bras. Cardiol., v.93, n.6, p.672-678, 2009. 
SÃO PAULO (Estado). Centro de Vigilância Epidemiológica "Professor Alexandre Vranjac" - Divisão de Doenças Crônicas Não Transmissíveis. PLUCIENNIK, A.M.A. Hipertensão arterial: medicamento hipertensivo: vale pena prescrever o mais caro? Available at: <http://www.cve. saude.sp.gov.br/htm/cronicas/dent_hiper.htm $>$. Accessed on: 01 aug. 2010.

SICA, D.A. Rationale for fixed-dose combinations in the treatment of hypertension: the cycle repeats. Drugs, v.13, n.1, p.30-46, 2002.

SOCIEDADE BRASILEIRA DE CARDIOLOGIA. Tratamento medicamentoso. Available at: < http://departamentos. cardiol.br/dha/revista/9-4/tratamento2.pdf $>$. Accessed on: 01 aug. 2010.

SOCIEDADE BRASILEIRA DE CARDIOLOGIA. SOCIEDADE BRASILEIRA DE HIPERTENSÃO. SOCIEDADE BRASILEIRA DE NEFROLOGIA. VI Diretrizes Brasileiras de hipertensão arterial. Arq. Bras. Cardiol., v.95, suppl.1, p.1-51, 2010.
SOUSA, J.A.R. Para entender a saúde publica no Brasil. In:__. Gerenciamento do benefício em medicamento instrumento de informação para prevenção e promoção da saúde. 3.ed. São Paulo: LCTE, 2010. p.183-185.

TANIGUCHI, R. Pharmacy benefit management companies. Am. J. Health Syst. Pharm., v.52, n.17, p.1915-1917, 1995.

VIEIRA, F.S.; ZUCCHI, P. Distorções causadas pelas ações judiciais à política de medicamentos no Brasil. Rev. Saúde Pública, v.41, n.2, p.214-222, 2007.

WORLD HEALTH ORGANIZATION. WHO Collaborating Centre for Drug Statistics Methodology. Guidelines for ATC Classification and DDD assignment 2010. 13. ed. Oslo, 2009. Available at : < http://www.whocc.no/filearchive/ publications/2010guidelines.pdf $>$ Accessed on: 19 may. 2010.

Received for publication on $04^{\text {th }}$ May 2011 Accepted for publication on $08^{\text {rd }}$ August 2011 
